\title{
The Bildungsdrama and Alexander Ostrovsky's Plays
}

The term Bildungsroman is generally used in the theory of the novel to designate a text that contains a story exploring the formation of a hero. My research works with an understanding of the Bildungsroman (or 'novel of formation') as the genre associated with the Golden Age of the European novel in the nineteenth century: a biographical novel, the subject and the content of which is the story of the formation of a character in the process of his interaction with society. The story of this formation reflects the topical moral quest of the time in which the hero lives. ${ }^{1}$

Having studied a corpus of novels written from the 1840 s to the 1880 s as one megatext of the Russian Bildungsroman, I have argued that the Bildungsroman was one of the key genres in the Russian literary context of that time, synthesizing European and Russian traditions, shifting and adjusting to the topical issues in Russian society, and possessing a particular pattern, a formula that was perceived by the authors of that time. Building on this previous research, ${ }^{2}$ I now wish to approach the question of whether it is possible to apply the notion of Bildung to the study of a theatrical work. In other words, I would like to discuss whether one could use the term Bildungsdrama when analyzing Russian plays of the nineteenth century in particular. This question remains overlooked in modern literary studies. Nevertheless, there have been attempts to approach the issue of Bildungsdrama's presence (or absence) in literary contexts, and its legitimacy as a concept. In 1976, during the period of revival in Bildungsroman theory, Margaret

1 See, for example, the following two studies: Todd Curtis Kontje. The German Bildungsroman: History of a National Genre. Columbia, SC: Camden House, 1993; Karl Morgenstern and Tobias Boes. "On the Nature of the 'Bildungsroman'.” PMLA 124 (2009), pp. 647-659.

2 Cf. Natalia V. Sarana. "Russkaya 'Dzhenni Ir': Retseptsiya tvorchestva Sharlotty Bronte v romane YU.V. Zhadovskoy 'Zhenskaya istoriya' (1860)” [The Russian "Jane Eyre”: The reception of Charlotte Brontë in Yulia V. Zhadovskaya's novel Women's History (1860)]. Vestnik Moskovskogo universiteta, seriya 9, Filologiya (2018), pp. 173-181; "Angliyskiy 'sopernik' romana Goncharova: obyknovennaya istoriya ili prostaya?” [An English "rival” to Goncharov's novels...] Vestnik Tverskogo gosudarstvennogo universiteta, seriya: Filologiya (2017), pp. 262-267; "Angliyskiy 'repertuar' kak element polemicheskoy retseptsii A. F.Pisemskogo" [English "repertoire” as a factor in the polemical reception of Alexey Pisemsky]. Russkaya filologiya 27: Sbornik nauchnykh rabot molodykh filologov. Tartu: Tartu University Press, 2016, pp. 82-92; “Anna Karenina, the "English Novel.': Towards the Study of Anglomania in Leo Tolstoy 's Novel Anna Karenina.” ENTHYMEMA 11 (2014), pp. 58-63.

Ә Open Access. (c) 2019 Natalia V. Sarana, published by De Gruyter. (c) BY-NC-ND This work is licensed under the Creative Commons Attribution-NonCommercial-NoDerivatives 4.0 License. https://doi.org/10.1515/9783110604276-012 
Scholl was, to our knowledge, the first English-speaking scholar to approach the question why the word "Bildungsdrama" had never been used as a literary term. Her answer is more or less obvious for scholars of the Bildungsroman:

Perhaps that is because of the seeming contradiction in the word itself. "Bildung" implies time, time necessary for a person to mature, and most drama takes place in a matter of hours or at most, days. Even drama that covers a longer period of historical time is limited in stage time. It therefore seems unlikely that the dramatic hero could undergo anything as complex as a "Bildungsprozess" in the short time span covered by the drama. ${ }^{3}$

While pointing out this contradiction, she notes that it should not stop scholars from investigating this genre which, according to Scholl, appeared at the same time as the Bildungsroman, in the last part of the eighteenth century. For my research, I am most interested in Scholl's ensuing remark that, paradoxically, the contrasting aspect of time in a novel and in a theatrical work gives the latter the opportunity for just as powerful an idea of Bildung as the Bildungsroman. Scholl states that "the authors [of drama] intentionally place their heroes in a situation where they must eventually accept the superiority, and the righteousness, of a reality outside themselves."4 One may say that this "ethical tendency" described by Scholl is almost congenital in Alexander Ostrovsky's plays. Therefore, the purpose of this article is to isolate the idea of Bildung from the theory of the novel and to demonstrate that the story of one's development can be told by means of drama. Moreover, it has its precedent in the history of Russian drama from the 1850 s to the 1880 s.

This article will analyze several plays by Alexander Ostrovsky, among them Groza (The Storm;1859), Zhenit'ba Belugina (Belugin's Marriage; 1877), Bespridannitsa (Without a Dowry; 1879), and Bez viny vinovatye (Guilty Innocents or Innocent as Charged; 1884). Comparing them will provide insights into the dramatic possibilities of the hero's formation story.

Olga Kuptsova has recently published an article entitled "To Study or to Marry?," in which she uses the term 'educational comedy' when referring to Ostrovsky's comedies that explore the different modes of education that Ostrovsky's heroes receive, as well as the problems of fathers and sons arising from this. While this approach is invaluable for the study of Ostrovsky's idea of education, which he defined within the broader context of educational debates in Russian society of that time, it is proposed within the framework of the current article to shift the focus from the educational system and the debates associated

3 Margaret Scholl. The Bildungsdrama of the Age of Goethe. Bern: Lang, 1976, p. 11. 4 Ibid., p. 12. 
with it to the study of a classic hero of a Bildungsroman and his/her formation and development.

In analyzing the theories of Bildung within the context of drama, one sometimes finds oneself on the borderline between literary studies and drama theory. It could be argued that drama theory may also be of use in the current research. For example, in an article entitled "Exploring the Notion of Bildung in Theatre Work: Conversations with Actors Rehearsing Brecht's Fatzer” (2014), Stig A. Eriksson cites the work Bildning och teater [Bildung and Theater] (2005) by the Swedish theater researcher Alexandra Ahndoril, in which it is hypothesized that the Bildung possibilities are endless when it comes to the theater. Bildning och teater is Ahndoril's essay on her own experience as a professional actress and author. It provides "a set of deliberations about theater as an educative force." 5

Eriksson argues that Ahndoril's work provides valuable insights into the educational potential and characteristics of theater which convert it into a force capable of creating the notion of Bildung, including appreciating, and engaging in, the experience of others, accepting new circumstances, embracing shifts in perspective, etc. In order to frame the notion of story and exemplification, Ahndoril uses Sophocles' Oedipus the King and discusses Oedipus' journey as a form of Bildung. Thus, drama theory and practice can provide an additional framework within the context of current research on the notion of Bildung in theater works.

Conversely, reference should be made to the Russian drama from the 1860 s to the 1880s in order to research the topic of drama and Bildung in correlation with the Russian literature of that time. During this period, Ostrovsky was himself researching the psychological and educational possibilities of drama. The ideas of the French Enlightenment and the broader context of the European theory of Bildung, including the European Bildungsroman, may have had an influence on the educational aspect of Ostrovsky's works.

Several plays by Ostrovsky will now be discussed, to argue that Ostrovsky's works present the key elements of a study of the hero's formation story through dramatic means. The first play I would like to discuss in relation to the aesthetics of Bildung is Zhenit'ba Belugina (Belugin's Marriage). In Zhenit'ba Belugina, written in 1877, the process of formation occurs through marriage. Marriage, whether it be the concluding chapter in a story of a woman's life or the challenge she is or is not willing to undertake, always plays the crucial role in the narration of female experience in literary works of the 1800s. Hence, in my view, this play should be

5 Stig A. Eriksson. "Exploring the Notion of Bildung in Theatre Work: Conversations with Actors Rehearsing Brecht's Fatzer.” Drama Australia National Journal (NJ) 38 (2014), pp. 8-24, p. 12. 
analyzed within the broader process of feminine Bildung and its representation in literary works of that time, as actively present in the Russian literary context. In my other work relating to the feminine Bildungsroman in the Russian literary context, ${ }^{6}$ I have argued that its presence in Russian literature is derived from similar processes occurring in the British literature of that time. In Elaine Hoffman Baruch's article "The Feminine Bildungsroman: Education through Marriage," the author argues as follows:

If the central theme of the Bildungsroman is the education of the hero, who is brought to a high level of consciousness through a series of experiences that lead to his development, then many of the great novels that deal with women treat similar themes. From Emma to Jane Eyre to Madame Bovary to Middlemarch to Anna Karenina to Portrait of a Lady to Lady Chatterley's Lover and beyond, the novel presents a search for self, an education of the mind and feelings. But unlike the male Bildungsroman, the feminine Bildung takes place in or on the periphery of marriage. In some cases, the heroines of these novels seek successful marriage, sometimes, as Jane Eyre, they long for 'expanded experience'?

Elena, the bride and wife in Zhenit'ba Belugina, agrees to marry Belugin solely for the sake of money, while being persuaded by her lover, Agishin, to start the life of an adulteress. Over the course of the five acts, Elena undergoes a dramatic transformation from a frivolous and greedy young lady to a woman who not only realizes that her not-so-educated merchant husband is far wiser than she is, but also refuses the path of an adulterous lover, saying that, while a mind can be persuaded to do almost anything, the will cannot:

Агишин. Ну, да как хотите рассуждайте; а вы сделали ошибку большую! Задумали-то хорошо, а исполнить - характера не хватило. Вот плоды сентиментального воспитания.

Елена. Да, то есть ум-то вы успели во мне развратить, а волю-то не умели - вот вы о чем жалеете! Помешали вам мои хорошие природные инстинкты. А я этому очень рада... ${ }^{8}$

Agishin. Well, think as you may; but you made a big mistake! The idea was good, but you lacked the character to carry it out. These are the fruits of sentimental education.

Elena. Yes, well you have managed to spoil my mind, but you didn't succeed with my will this is what you regret! My strong natural instincts didn't let you do it. And I am very happy about it..."9

6 Cf. n.2.

7 Elaine Hoffman Baruch. "The Feminine Bildungsroman: Education through Marriage.” The Massachusetts Review 22 (1981), pp. 335-357, p. 339.

8 Alexander Ostrovsky. Polnoe Sobranie Sočinenij [Complete Works], vol. 8. Moscow: s.n., 1950, pp. 213-214.

9 Translations from Ostrovsky's plays are mine. 
The topic of feminine Bildung is also addressed in plays such as Groza (The Storm) and Bespridannitsa (Without a Dowry). These two plays are invaluable to the study of Russian Bildung in the context of drama. In these texts, the key conflict results from the necessity of marriage as women's only option to complete their formation. In Bespridannitsa, the heroine, Larisa Ogudalova, is forced to get married not only by the social norms of the time, but also by her mother. She is deprived of the right to "the expanded experience," and so the only experience she can afford is that of a marriage:

Разве мне самой такая жизнь нравилась? Мне было приказано, так нужно было маменьке; значит, волей или неволей, я должна была вести такую жизнь. Вы видите, я стою на распутье; поддержите меня, мне нужно ободрение, сочувствие; отнеситесь ко мне нежно, с лаской! Ловите эти минуты, не пропустите их! ${ }^{10}$

Do you think I liked this sort of life? I was told to live it by my mother, so, whether I want it or not, I have to lead a life like this. You can see I am standing at the crossroads; support me, I need compassion, reassurance; treat me with care and love! Catch these moments, do not miss them!

Unable to break free, or to come to terms with marrying a person who might give her a peaceful life, Larisa's life ends dramatically. In Groza, by contrast, the story of the heroine, Katerina, illustrates the future Larisa Ogudalova could have, if she were to enter into marriage willingly:

Катерина. Такая ли я была! Я жила, ни об чем не тужила, точно птичка на воле. Маменька во мне души не чаяла, наряжала меня, как куклу, работать не принуждала; что хочу, бывало, то и делаю [...]. Ничего мне не надобно, всего у меня было довольно. А какие сны мне снились...[...].А то будто я летаю, так и летаю по воздуху. И теперь иногда снится, да редко, да и не то. ${ }^{11}$

Katerina. How different I used to be! I lived without a care in my heart, as free as a bird. Mother adored me, dressed up like a doll, and never forced me to work; I could do just as I liked [...]. I wanted nothing, I had enough of everything. And what dreams I used to have... [...] Sometimes I seemed to be flying, simply flying in the air. I dream sometimes now, but not often, and never dreams like those.

Katerina begins to realize that she cannot live under her present circumstances. Although she appears to be fond of her husband, she is not granted the opportunity to embrace her own development:

10 Alexander Ostrovsky. Polnoe Sobranie Sočinenij [Complete Works], vol. 10. Moscow: s.n., 1951, pp. 169-170.

11 Alexander Ostrovsky. Polnoe Sobranie Sočinenij [Complete Works], vol. 2. Moscow: s.n., 1950, pp. 222-223. 
Катерина. Сделается мне так душно, так душно дома, что бежала бы. И такая мысль придет на меня, что, кабы моя воля, каталась бы я теперь по Волге, на лодке, с песнями, либо на тройке на хорошей, обнявшись... ${ }^{12}$

Katerina: I am stifled, stifled at home, I should like to run away. And the fancy comes to me that if I were my own mistress, I would float down the Volga now, in a boat, to the singing of songs, or I would, I would drive right away clasped close...

When discussing the key Bildung features present in Ostrovsky's plays, it may be argued that Bez viny vinovatye (Guilty Innocents) serves as the most elaborate example of theatrical works constructed around the notion of Bildung. As opposed to the plays discussed earlier in this paper, Bez viny vinovatye not only follows the idea of a hero's formation, but also uses methods that bring it closer than any other play by Ostrovsky to a classic Bildungsroman.

The play follows the story of a heroine called Otradina, who later appears in the text as Kruchinina. Ostrovsky depicts the full story of the heroine's formation, paralleling the key element of a Bildungsroman. The readers first meet Otradina as a young girl who is on the verge of a personal drama: she is soon left by her lover and has to suffer through the death of their child. It is worth noting that money as the root of all evil (here, Otradina's inability to marry the man she loves) is perceived in this context, as well as in many other Ostrovsky plays, as the misfortune that sets the hero's formation story in motion. The story of Otradina then breaks off for seventeen years, up until the moment when she returns to her hometown disguised as the famous actress Kruchinina. She has already gone through the key stages in the classic story of a hero's development.

In his study The Way of the World: The Bildungsroman in European Culture, ${ }^{13}$ Franco Moretti hints that the Bildungsroman follows the structure of a fairytale, the morphology of which was developed in a fundamental work by Vladimir Propp. Applying Propp's definition of a fairytale to the story of Kruchinina's life clarifies the patterns of her development. She has undergone the journey, characterized in a Russian idiom as a journey through "fire, water, and brass pipes," in which the brass pipes stand for fame or flattery. Having first been cheated on by her lover, having then lost her child, she has become a successful actress, yet she continues to be a humble and generous woman. Seventeen years later, her story of development is nearly completed. This sequence of events culminates in a dramatic moment in which the heroine of the story finally receives her reward. It comes in the form of divine providence, namely in the figure of her son who was hitherto thought to be dead. Neznamov, one of the actors in

12 Ostrovsky, Polnoe Sobranie Sočinenij, vol. 2, p. 223.

13 London: Verso, 1987. 
the local theater, turns out to be her son. Although the main function of that character in Ostrovsky's play is that of rewarding Kruchinina with the return of her child, he is also described as a hero in his own right, having gone through a classic story of development. Neznamov's story is told to Kruchinina by one of his fellow actors:

Дудукин. Я изложу вам краткую биографию его, как он мне сам передавал. Ни отца, ни матери он не помнит и не знает, рос и воспитывался он где-то далеко, чуть не на границах Сибири, в доме каких-то бездетных, но достаточных супругов из мира чиновников, которых долгое время считал за родителей. Его любили, с ним обращались хорошо, хотя не без того чтобы под сердитую руку не попрекнуть его незаконным происхождением. Разумеется, он их слов не понимал и разобрал их значение только впоследствии. Его даже учили: он бегал в какой-то дешевенький пансион и получил порядочное для провинциального артиста образование. Так он прожил лет до пятнадцати, потом начались страдания, о которых он без ужаса вспомнить не может. Чиновник умер, а вдова его вышла замуж за отставного землемера, пошло бесконечное пьянство, ссоры и драки, в которых прежде всего доставалось ему. Его прогнали в кухню и кормили вместе с прислугой; часто по ночам его выталкивали из дому, и ему приходилось ночевать под открытым небом. А иногда от брани и побоев он и сам уходил и пропадал по неделе, проживал кой-где с поденщиками, нищими и всякими бродягами, и с этого времени, кроме позорной брани, он уж никаких других слов не слыхал от людей. В такой жизни он озлобился и одичал до того, что стал кусаться как зверь. Наконец, в одно прекрасное утро его из дому совсем выгнали; тогда он пристал к какой-то бродячей труппе и переехал с ней в другой город. Оттуда его, за неимение законного вида, отправили по этапу на место жительства. Документы его оказались затерянными; волочили, волочили его, наконец выдали какую-то копию с явочного прошения, с которой он и стал переезжать с антрепренерами из города в город, под вечным страхом, что каждую минуту полиция может препроводить его на родину. ${ }^{14}$

Dudukin. I am going to present a short biography of him, as he told it to me. He remembers neither his father nor mother, he was raised somewhere far away, almost on the borders of Siberia, in the house of a childless but quite wealthy couple from the class of officials, whom he took for his parents for a long time. He was loved, he was treated well, although not without being reproached for his illegal origin on occasion. Of course, he did not understand their words until later in his life. He was even educated; he went to some cheap boarding school and got a decent education for a provincial actor. In such a way he spent his last fifteen years, then sufferings began which he cannot recall without horror. The officer died, and his widow married a retired surveyor who would drink, quarrel, and fight endlessly. He, Neznamov, bore the brunt of the situation. He was sent into the kitchen to live together with the servants; at night, they often threw him out of the house, and he had to spend the night on the streets. And sometimes, tired of abuse and beatings, he went away of his own

14 Alexander Ostrovsky. Polnoe Sobranie Sočinenij [Complete Works], vol. 9. Moscow: s.n., 1951, pp. 168-169. 
volition and vanished for a week, living here and there with the day laborers, beggars, and all sorts of vagrants. And from that time on, he heard no words from other people except for shameful swearing and cursing. Because of this life, he became embittered and got so wild that he could bite like an animal. Finally, one morning he was kicked out of the house for good; then he joined some wandering troupe and moved to another city. From there he was, for lack of a legal residence-permit, sent under escort to his place of residence. His documents turned out to be lost; he was dragged and dragged about, until he was finally given [the required papers], with which he began to move [...] from city to city, under the perpetual fear that at any moment the police might transmit him to his homeland.

Neznamov's development is subsequently presented in more detail in the text. He starts to travel with a theater troupe from town to town. This part of Neznamov's journey resembles the story of the classic Bildungsroman, namely Goethe's Wilhelm Meister. Neznamov's journey, recounted in one passage by his fellow actor, corresponds to the most basic plot of a Bildungsroman. The only point lacking in his story of development is the end. Oppressed and disappointed throughout his journey, he finally receives a hero's reward, namely the "mother's touch," the reunion with his biological mother, which brings not only his own story of formation, but also Kruchinina's journey to a close.

In conclusion, I would like to emphasize that the drama of Bildung, or the Bildungsdrama, the term I would propose in this context, can be analyzed from an educational point of view as a dramatic debate on the contemporary educational system. In the present paper, an attempt has been made to demonstrate that the textual analysis of a hero's upbringing and formation can be illustrated and achieved by dramatic means, thus contributing to the debate on whether the idea of Bildung is only present within the context of a Bildungsroman or may also be achieved in other literary genres. I would argue that the texts by Ostrovsky discussed above prove the latter claim correct. 